\title{
WISP-2 in human gastric cancer and its potential metastatic suppressor role in gastric cancer cells mediated by JNK and PLC- $\gamma$ pathways
}

Jiafu $\mathrm{Ji}^{\star}, 1,2$, Shuqin $\mathrm{Jia}^{2,3}$, Yongning $\mathrm{Jia}^{1,2}, \mathrm{Ke} \mathrm{Ji}^{2}$, Rachel Hargest ${ }^{2}$ and Wen G Jiang ${ }^{\star, 2}$

${ }^{1}$ Key Laboratory of Carcinogenesis and Translational Research (Ministry of Education), Peking University Cancer Hospital and Institute, No. 52, Beijing 100142, China; ${ }^{2}$ Cardiff University-Peking University Cancer Institute, Cardiff University School of Medicine, Cardiff, UK and ${ }^{3}$ Laboratory of Molecular Oncology, Key Laboratory of Carcinogenesis and Translational Research (Ministry of Education), Laboratory of Molecular Oncology, Peking University Cancer Hospital and Institute, No. 52, Beijing 100142, China

Background: It has recently been shown that WISP proteins (Wnt-inducted secreted proteins), a group of intra- and extra-cellular regulatory proteins, have been implicated in the initiation and progression of a variety of tumour types including colorectal and breast cancer. However, the role of WISP proteins in gastric cancer (GC) cells and their clinical implications have not yet been elucidated.

Methods: The expression of WISP molecules in a cohort of GC patients was analysed using real-time quantitative PCR and immunohistochemistry. The expression of a panel of recognised epithelial-mesenchymal transition (EMT) markers was quantified using Q-PCR in paired tumour and normal tissues. WISP-2 knockdown $(\mathrm{kd})$ sublines using ribozyme transgenes were created in the GC cell lines AGS and HGC27. Subsequently, several biological functions, including cell growth, adhesion, migration and invasion, were studied. Potential pathways for the interaction of EMT, extracellular matrix and MMP were evaluated.

Results: Overexpression of WISP-2 was detected in GC and significantly correlated with early tumour node-metastasis staging, differentiation status and positively correlated with overall survival and disease-free survival of the patients. WISP-2 expression was inversely correlated with that of Twist and Slug in paired samples. Kd of WISP-2 expression promoted the proliferation, migration and invasion of GC cells. WISP-2 suppressed GC cell metastasis through reversing EMT and suppressing the expression and activity of MMP9 and MMP2 via JNK and ERK. Cell motility analysis indicated that WISP-2 kd contributed to GC cells' motility and can be attenuated by PLC- $\gamma$ and JNK small inhibitors.

Conclusions: Increased expression of WISP-2 in GC is positively correlated with favourable clinical features and the survival of patients with GC and is a negative regulator of growth, migration and invasion in GC cells. These findings suggest that WISP-2 is a potential tumour suppressor in GC.

The multistep process of tumour development involves the cell acquiring new phenotypic traits, including overriding growth controls, induction of angiogenesis, evasion from host antitumour responses, extravasation and growth at metastatic sites under the influence of successive genetic alterations and environmental factors. In patients with solid tumours, the main cause of death is not the primary neoplasm, but metastases in the vital organs (Leber and Efferth, 2009). The overall growth behaviour of a developing neoplasm is a net result of the combined kinetic interactions between heterogenous tumour cells

*Correspondence: Professor J Ji; E-mail: Jiafuj@hotmail.com or Professor WG Jiang; E-mail: JiangW@cardiff.ac.uk

Received 26 November 2014; revised 8 July 2015; accepted 11 July 2015; published online 20 August 2015

(c) 2015 Cancer Research UK. All rights reserved 0007-0920/15 
and the host. Intriguingly, the dominant influence of migration on tumour growth is dependent on the balance between tumour cell proliferation and death (Enderling et al, 2009). During the development of metastases, a number of processes occur, including epithelial-mesenchymal transition (EMT), migration and invasion, anoikis resistance, extravasation and organ colonisation.

WISP proteins (WNT1-inducible signalling pathway proteins) are a subfamily of the CCN super family (Pennica et al, 1998). The CCN family of proteins is a crucial group of signalling molecules found in eukaryotic organisms. The first three members of the family are Cyr61 (cysteine-rich protein 61), connective tissue growth factor and NOV (nephroblastoma overexpressed gene; Bork, 1993), which are now designated as CCN1, CCN2 and CCN3. There are three other family members WISP-1, WISP-2 and WISP-3, which are designated as CCN4, CCN5 and CCN6 (Brigstock, 2003). It has been shown that WISP proteins are upregulated in Wnt-1-transformed cells (Pennica et al, 1998).

As a part of the extracellular matrix (ECM), WISP proteins modulate various cellular activities, such as cell growth, differentiation, invasion, migration and survival (Chen and Lau, 2009). WISP-1 expression has been found in several cell types and implicated in cellular and tissue homeostasis through a variety of autocrine and paracrine loops, thereby representing a highly attractive target for therapeutic applications. Elevated WISP-1 expression has recently been reported in several cancers, including hepatocellular carcinoma (Calvisi et al, 2005), colon adenocarcinoma (Tian et al, 2007; Davies et al, 2010), lung carcinoma (Soon et al, 2003; Chen et al, 2007) and breast cancer (Xie et al, 2001; Davies et al, 2007). However, the functional mechanisms of WISP-1 in tumour development and progression are still controversial. The structural difference between WISP-2 and other WISP members is the absence of the carboxyl-terminal domain (Brigstock, 2003; Russo and Castellot, 2010). WISP-2 has been related to tumorigenesis and malignant transformation, especially in breast cancer (Zoubine et al, 2001; Davies et al, 2007), colorectal cancer (Davies et al, 2010) and hepatocellular carcinoma (Cervello et al, 2004). However, it appears that the WISP-2 functions are tissuespecific and influenced by the tumour microenvironment. Furthermore, it has been speculated that WISP-2 acts as a dominant negative regulator of other CCN family members, because of its structural difference from other WISP members. WISP-3 is the least-studied WISP member, which is a secreted protein that modulates the insulin-like growth factor-1 signalling pathway. WISP-3 was found to have tumour growth, proliferation and invasion inhibitory functions in inflammatory breast cancer and aggressive non-inflammatory breast cancer (Lorenzatti et al, 2011).

Clinical studies have revealed differential WISP expression profiles among different types of tumours along with different functions. The discordant results obtained from different cancers have raised uncertainty as to the role of WISP in carcinogenesis and metastasis per se. It has become apparent that the relative abundance of individual WISPs members, which often have contradictory activities, has a net effect on tumour progression. It has also been suggested that the relative abundance of WISP-1, WISP-2 and WISP-3 may be harnessed for a novel therapeutic approach to highly invasive cancers.

In this study, we determined the expression of WISP family members at both mRNA and protein levels in gastric cancer (GC) specimens and their adjacent normal tissues, as well as in different GC cell lines. Our data showed that WISP family members have different expression profiles in GC. Moreover, in vitro studies suggest loss of WISP-2 signalling may be a crucial permissive event for EMT and ECM degradation and cell migration.

\section{MATERIALS AND METHODS}

Chemicals. We purchased the following materials from Life Technologies (Paisley, Scotland, UK): PCR primers, molecularbiology-grade agarose, DNA ladder, pEF6/V5-His-TOPO plasmid vector and competent One Shot TOP10 E. coli. We obtained the Mastermix for routine PCR and quantitative PCR from Thermo Fisher Scientific (Surrey, UK). WISP-1, 2 and 3 antibodies were purchased from Abgent Inc. (Atlanta, GA, USA; Cat Number: AP6255a, AP6256a and AP6257a). Anti-GAPHD antibody was from Santa Cruz Biotechnologies Inc (Santa Cruz, CA, USA). A potent PLC- $\gamma$-specific inhibitor known as STK-870702 or known as 3-amino-N-(3-chlorophenyl)-5-oxo-5,6,7,8-tetrahydrothieno[2,3-b] quinoline-2-carboxamide, derived from thieno $[2,3-b]$ pyridine, was purchased from Vitas-M Laboratory, Ltd (Apeldoorn, The Netherlands; Cat number: STK870702; Feng et al, 2012; Leung et al, 2014) and a generic PLC inhibitor, U73122 was from Tocris Bioscience (Bristol, UK). The FAK inhibitor (PF573228, Cat Number: 3239) was from Tocris Bioscience; JNKII inhibitor (SP600125, Cat Number: 420119) was from Merck (Darmstadt, Germany); N-WASP inhibitor (Wiskostatin, Cat Number: 681525) was from Calbiochem (Watford, Herts, UK). The MMP9 inhibitor (Marimastat, Cat number: 2631) and MMP2 inhibitor (ARP100, Cat number: 2621) were both from Tocris Bioscience; Matrigel was from BD Bio-Science (Oxford, UK; Cat Number: 354234). ECIS 96W1E + arrays and culturewares were from Applied Biophysics Inc. (ECIS, Troy, NY, USA). TRI Reagent was from Sigma (SigmaAldrich, Inc., Poole, UK) and first strand cDNA was synthesised using iScript cDNA Synthesis Kit (Bio-Rad Laboratories, Inc., Hercules, CA, USA).

Human gastric tumour tissues. A total of 324 patients (male 231, female 93; mean age 59.8 years; range $23-87$ years: median survival 24 months) with GC, who were diagnosed and surgically treated at the Peking University Cancer Hospital between 2004 and 2007, were enrolled in this study. The study was approved by the local ethics committee (Ethics Number: 2006021) and consent was obtained from patients. Some of the patients had received chemotherapy or radiation therapy preoperatively. The following histopathological information was collected: depth of tumour invasion, histological grade, status of lymph node metastasis, presence or absence of liver metastases and vascular invasion. Staging of GC was classified according to the 1997 tumour nodemetastasis (TNM) classification recommended by the International Union Against Carcinoma. All patients were followed up until June 2012.

Gastric cancer cell lines. Two gastric cell lines, AGS and HGC27, were acquired from the European Collection of Animal Cell Culture (Salisbury, UK). Cells were maintained in DMEM-F12 medium supplemented with $10 \%$ fetal bovine serum and antibiotics.

RNA extraction and RT-PCR. A measure of 50-100 mg of frozen tissue or cells from a $25-\mathrm{cm}^{2}$ culture flask were homogenised and placed into $1 \mathrm{ml}$ of TRI reagent for RNA extraction. The homogenate was then precipitated with chloroform and isopropanol. The resultant RNA pellet was resuspended in DEPC water. The concentration of RNA was determined using a UV spectrophotometer. First strand cDNA was synthesised using iScript cDNA Synthesis Kit, and the quality of the cDNA was verified using GAPDH primers. PCR was performed using GreenTaq ReadyMix PCR reaction mix. Cycling conditions were $94^{\circ} \mathrm{C}$ for $5 \mathrm{~min}$, followed by $28-30$ cycles at $94^{\circ} \mathrm{C}$ for $30 \mathrm{~s}, 55^{\circ} \mathrm{C}$ for $30 \mathrm{~s}$ and $72{ }^{\circ} \mathrm{C}$ for $40 \mathrm{~s}$. This was followed by a final extension of $10 \mathrm{~min}$ at $72{ }^{\circ} \mathrm{C}$. The products were visualised in $1-2 \%$ agarose gels stained 
with SYBR green. All the primers used in this study are listed in Supplementary Table 1.

Western blotting. Cells were lysed by sonication in lysis buffer at $4{ }^{\circ} \mathrm{C}$. Lysates were centrifuged, supernatants were collected and total protein concentrations were determined by the BCA reagent assay (Pierce, Paisley, Scotland, UK). Western blot analysis was performed on $10 \%$ SDS-PAGE gel and transfer onto nitrocellulose membranes. The WISP-2 protein was detected with anti-WISP-2 antibody $(1: 200)$ using a SNAP-id 2.0 machine (Millipore, Watford, Herts, UK). Resultant western blot bands were normalised against GAPDH $(1: 5000)$.

Quantitative analysis of WISP family members and EMT markers in tissues. The mRNA levels of WISP-1, WISP-2, WISP-3 and the EMT markers (E-cadherin, Slug and Twist), in the cDNA prepared as above, were determined by real-time quantitative PCR using IcyclerIQ (Bio-Rad, Hemel Hempstead, UK), based on the Amplifluor technology (Nazarenko et al, 1997), which was modified from a previously reported method (Jiang et al, 2003). Cytokeratin19 was used as a control during the 96 cycles of analysis. Primer details are given in Table 1 . The reaction was carried out under the following conditions: $94^{\circ} \mathrm{C}$ for $5 \mathrm{~min}, 96$ cycles at $94{ }^{\circ} \mathrm{C}$ for $15 \mathrm{~s}$, $55^{\circ} \mathrm{C}$ for $35 \mathrm{~s}$ and $72{ }^{\circ} \mathrm{C}$ for $20 \mathrm{~s}$. The levels of the transcripts were generated using an internal standard that was simultaneously amplified with the samples, and the results are shown in two ways: levels of transcripts based on equivalent amounts of mRNA and as a target/cytokeratin-19 ratio (Davies et al, 2010).

Immunohistochemical staining of WISP family proteins. Immunohistochemistry was performed in 316 cases of pathological sections. Sections of $4 \mu \mathrm{m}$ thickness, prepared from formalin-fixed, paraffin-embedded tissues were mounted on poly-L-lysine-coated glass slides. They were then de-paraffinised in xylene and rehydrated through alcohol to distilled water. Endogenous peroxidase activity was blocked with $3 \%$ hydrogen peroxide for $15 \mathrm{~min}$ at room temperature. After pressure cooking the sections in $10 \mathrm{mmoll}^{-1}$ EDTA ( $\mathrm{pH} 8.0$ ) for $3 \mathrm{~min}$, they were incubated at room temperature with anti-WISP-1,WISP-2 and WISP-3 antibodies $(1: 50,1: 100$ and $1: 50$ dilution, respectively) for $3 \mathrm{~h}$, followed by incubation with HRP-conjugated secondary antibody. Development of slides was performed using peroxidase substrate (diaminobenzidine tetrahydrochloride) solution, followed by counterstaining with hematoxylin, dehydration in ethanol and clearing with xylene. Normal human mammary epithelium was used as positive control and normal gastric mucosa stained with PBS as primary antibody was used as a negative control. The degree of polyclonal WISP-1, WISP-2 and WISP-3 antibody reactivity was scored by assessing the percentage of stained

Table 1. Association of WISP-1, WISP-2 and WISP-3 mRNA expression with clinicopathological parameters in GC patients

\begin{tabular}{|c|c|c|c|c|c|c|c|c|c|c|c|c|}
\hline \multirow[b]{2}{*}{$\begin{array}{l}\text { Clinicolpathological } \\
\text { parameters }\end{array}$} & \multicolumn{4}{|c|}{ WISP-1 } & \multicolumn{4}{|c|}{ WISP-2 } & \multicolumn{4}{|c|}{ WISP-3 } \\
\hline & Cases & $N^{\alpha}$ & $\begin{array}{l}\text { Median } \\
(\mathrm{Q} 1, \mathrm{Q} 3)\end{array}$ & $P$ & Cases & $\mathbf{N}^{\alpha}$ & $\begin{array}{l}\text { Median } \\
(\mathrm{Q} 1, \mathrm{Q} 3)\end{array}$ & $P$ & Cases & $\mathbf{N}^{\alpha}$ & $\begin{array}{l}\text { Median } \\
(\mathrm{Q} 1, \mathrm{Q} 3)\end{array}$ & $P$ \\
\hline \multicolumn{13}{|l|}{ Tissue sample } \\
\hline Normal & 158 & 31 & $5(0,243)$ & & 182 & 7 & $1.3(0.1,58.9)$ & & 155 & 34 & $0(0,499)$ & \\
\hline Tumour & 260 & 64 & $0(0,135)$ & 0.0642 & 320 & 4 & $4.9(0,28)$ & $0.0028^{\star \star}$ & 227 & 97 & $0(0,257)$ & 0.9076 \\
\hline \multicolumn{13}{|l|}{ Gender } \\
\hline Male & 185 & 46 & $0(0,126)$ & & 230 & 1 & $4.9(0.1,55)$ & & 159 & 72 & $0(0,327)$ & \\
\hline Female & 75 & 18 & $3(0,501)$ & 0.12 & 90 & 3 & $5.1(0.2,69.6)$ & 0.8387 & 68 & 25 & $0(0,2241)$ & 0.7591 \\
\hline \multicolumn{13}{|l|}{ Infiltration depth } \\
\hline $\mathrm{T} 1+\mathrm{T} 2$ & 40 & 2 & $2(0,611)$ & & 41 & 1 & $15.9(1.1,116.9)$ & & 32 & 10 & $1(0,7706)$ & 0.1337 \\
\hline $\mathrm{T} 3+\mathrm{T} 4$ & 213 & 61 & $0(0,130)$ & 0.3487 & 271 & 3 & $4.6(0.1,58.9)$ & 0.1817 & 191 & 83 & $0(0,281)$ & \\
\hline \multicolumn{13}{|l|}{ Lymph node status } \\
\hline NO & 55 & 16 & $0(0,468)$ & & 69 & 2 & $14.8(0.4,83.4)$ & & 51 & 20 & $0(0,537)$ & \\
\hline $\mathrm{N} 1+2+3$ & 201 & 46 & $0(0,126)$ & 0.716 & 133 & 1 & $4(0.1,55)$ & 0.128 & 173 & 74 & $0(0,363)$ & 0.5634 \\
\hline \multicolumn{13}{|l|}{ M-staging } \\
\hline $\mathrm{MO}$ & 227 & 55 & $1(0,269)$ & & 278 & 4 & $5.4(0.2,63.1)$ & & 192 & 84 & $0(0,651)$ & \\
\hline M1 & 33 & 8 & $0(0,11)$ & $0.0168^{\star}$ & 41 & 0 & $4(0,45)$ & 0.39 & 29 & 12 & $0(0,0)$ & 0.103 \\
\hline \multicolumn{13}{|l|}{ TNM staging } \\
\hline TNM1 + 2 & 70 & 15 & $1(0,759)$ & & 83 & 2 & $15.9(1.4,77.7)$ & & 62 & 23 & $1(0,9690)$ & \\
\hline $\mathrm{TNM} 3+4$ & 183 & 47 & $0(0,110)$ & 0.3029 & 228 & 2 & $3.2(0.1,50.5)$ & $0.0249 *$ & 161 & 69 & $0(0,79)$ & 0.136 \\
\hline \multicolumn{13}{|l|}{ Differentiation } \\
\hline High & 0 & 1 & & & 1 & 0 & & & 1 & 0 & & \\
\hline High-medium & 5 & 1 & $0(0,1232)$ & & 6 & 0 & $0.9(0.2,52.9)$ & & 4 & 2 & $0(0,37978)$ & \\
\hline Medium & 52 & 10 & $0(0,230)$ & $0.592^{a}$ & 60 & 2 & $5.3(0.1,76.4)$ & $0.7464^{a}$ & 40 & 22 & $0(0,407)$ & $0.7907^{a}$ \\
\hline Medium-low & 61 & 21 & $1(0,737)$ & $0.3264^{a}$ & 81 & 1 & $15.9(0.2,49.6)$ & $0.5028^{a}$ & 59 & 23 & $0(0,4211)$ & $0.9663^{a}$ \\
\hline Low & 112 & 26 & $1(0,82)$ & $0.5091^{a}$ & 137 & 1 & $5.2(0.2,78.4)$ & $0.5525^{a}$ & 100 & 38 & $0(0,427)$ & $0.8724^{a}$ \\
\hline \multicolumn{13}{|l|}{ Clinical outcome } \\
\hline Alive & 106 & 28 & $1(0,440)$ & & 133 & 1 & $9.1(0.2,92.4)$ & & 93 & 41 & $0(0,1074)$ & 0.2984 \\
\hline Died & 152 & 35 & $0(0,71)$ & 0.227 & 184 & 3 & $3.8(0.1,41.7)$ & 0.1698 & 132 & 55 & $0(0,231)$ & \\
\hline Disease-free & 94 & 25 & $0(0,440)$ & & 118 & 1 & $10.5(0.2,95.5)$ & & 82 & 37 & $0(0,1985)$ & \\
\hline metastasis & 12 & 3 & $1(0.873)$ & $0.8341^{b}$ & 15 & 0 & $1.9(0.1,31.6)$ & $0.4747^{b}$ & 11 & 4 & $0(0,5)$ & $0.8724^{b}$ \\
\hline Died of GC & 152 & 35 & $0(0,71)$ & $0.2529^{b}$ & 184 & 3 & $3.8(0.1,41.7)$ & $0.1236^{b}$ & 132 & 55 & $0(0,231)$ & $0.2548^{b}$ \\
\hline \multicolumn{13}{|c|}{$\begin{array}{l}\text { Abbreviations: } \mathrm{GC}=\text { gastric cancer } \\
{ }^{\mathrm{a}} \text { Compared with 'High-medium'. } \\
{ }^{\mathrm{b}} \text { Compared with 'Disease Free'. } \\
{ }^{\star} P<0.05 \text {. } \\
{ }^{* \star} P<0.01 \text {. }\end{array}$} \\
\hline
\end{tabular}


adenocarcinoma cells in the section. In this study, expression in GC specimens was defined as 'negative' (0-20\% stained cells) or 'positive' expression ( $>20 \%$ stained cells). Slides were analysed independently by two observers using light microscopy. Photographs were recorded on an Olympus CKX41 microscope. For representative images of WISP-2, see Figure 1.

Construction of anti-human WISP-2 ribozyme and knockdown (kd) of WISP-2 in GC cell lines. Anti-human WISP-2 hammerhead ribozyme sequences were designed based on the secondary structure of the mRNA generated using Zuker's RNA Mfold programme (Zuker, 2003). The ribozymes were synthesised and cloned into pEF6/V5-His-TOPO plasmid vector and then ribozyme transgenes and control plasmids were transfected into AGS and HGC27 cells, using an electroporator (Easject Plus; EquiBio, Ltd., Kent, UK). Stable transfectants were obtained after 2 weeks of selection using 5-7.5 $\mu \mathrm{g} \mathrm{ml}^{-1}$ blasticidin. We also used a plasmid in which the Ribozyme transgene was inserted in the 'wrong' direction (that is, sense direction) and a control. Multiple clones were combined and grown as a new population of sublines. RT-PCR, Q-RT-PCR and western blotting were used to verify the efficiency of knock down on the new sublines. Oligo sequences are given in Supplement 1.

In vitro cell growth assay. A standard procedure was used as previously described (Jiang et al, 2005). Gastric cells were plated into a 96 -well plate ( 3000 cells per well). Cells were fixed in $4 \%$ formalin after 1,3 and 5 days. The cells were then stained with $0.5 \%(\mathrm{w} / \mathrm{v})$ crystal violet for half an hour. Following washing, stained crystal violet was extracted with $10 \%(\mathrm{v} / \mathrm{v})$ acetic acid. Absorbance was determined at a wavelength of $540 \mathrm{~nm}$ using a spectrophotometer (Elx800; Bio-Tek, Bedfordshire, UK). Growth rate was calculated as follows:

Growth rate on day $5=\frac{\text { absorbance on day } 5}{\text { absorbance on day } 1} \times 100$

In vitro cell-matrix adhesion assay. A total of 40000 cells were added to each well of a 96-well plates previously prepared by coating with Matrigel ( $5 \mu \mathrm{g}$ per well). The cells were incubated at $37^{\circ} \mathrm{C}$ in $5 \% \mathrm{CO}_{2}$ for $40 \mathrm{~min}$ and the medium was then discarded. Nonadherent cells were washed off using BSS buffer. The remaining cells were then fixed in $4 \%$ formaldehyde for $5 \mathrm{~min}$. After further washing, cells were stained with crystal violet, and the number of adherent cells was then counted.

In vitro invasion assay. This was carried out as previously reported and modified in our laboratory (Jiang et al, 1995). Transwell inserts with $8 \mu \mathrm{m}$ pore size were coated with $50 \mu \mathrm{g}$ Matrigel and air-dried. The Matrigel was rehydrated before use. A total of 25000 cells were seeded to each well and after $72 \mathrm{~h}$, cells that had migrated through the matrix and pores were fixed with $4 \%$ formalin, stained in crystal violet and counted.

In vitro wounding assay. Cells were seeded into a 24 -well plate at a density of 200000 per well and allowed to form a monolayer, which was then scraped to create a wound about $200 \mu \mathrm{m}$ wide (Jiang et al, 1999). Migration of the cells at wounding edges was monitored and photographs were taken at $0.25,1,2,3$ and $4 \mathrm{~h}$ after wounding. Migration distances were measured using Image J software (www.ImageJ.net).

The effects of different small inhibitors on the cell motility. ECIS (Electric Cell-Substrate Impedance Sensing) is a novel method used as an alternative to conventional functional assays. It works with an array of 96 wells, each containing a gold electrode. These measure the current and voltage across this electrode, calculating the impedance and resistance. From the impedance changes, effects on cell attachment and motility can be examined (Keese et al, 2004). Using 96W1E + array, cell adhesion and wounding assay were also performed with ECIS. A total of 40000 cells diluted in $200 \mu$ l of DMEM were seeded into each ECIS plate well, and treated with a protein of interest. In this study, we treated the cells with different concentrations of PLC inhibitor U73122, FAK inhibitor PF573228 and JNK inhibitor SP100625. Inhibitors were first dissolved in DMSO (1 mM) and then diluted with serumfree medium to different concentrations. For the control group, an identical volume of serum-free medium was added into wells. The array was then placed into an ECIS $\mathrm{CO}_{2}$ incubator, which was connected to the ECIS Model 9600 Controller. Cell adhesiveness was assessed within the first $40 \mathrm{~min}$ and the electric wound was set at the 14th hour when the resistance reached maximum levels and migration data could be gathered continuously for $6 \mathrm{~h}$.

Quantitative analysis for EMT markers in cell lines. The levels of mRNA expression of EMT markers, E-cadherin, N-cadherin, Twist, Slug and Vimentin were determined by real-time quantitative PCR and RT-PCR in WISP-2 kd and control cells. GAPDH was used as an internal control. Primer details are given in Supplement 1.

Expression and activity of metalloproteinases (MMPs). The levels of mRNA expression of MMP1, MMP2, MMP3, MMP7 and MMP9 were determined by RT-PCR in WISP-2 kd and control cells. To test the activity of type IV collagenases MMP2 and MMP9, which are of the most important type of MMPs, $1 \times 10^{6}$ cells were seeded into a $25-\mathrm{cm}^{2}$ culture flask and incubated overnight. Following incubation, cells were washed once with sterile $1 \mathrm{x}$ BSS followed by a wash with serum-free DMEM and then either incubated in serum-free DMEM control or treated medium for $6 \mathrm{~h}$. In this study, we treated cells with $200 \mathrm{~nm}$ of JNKII or ERKII small inhibitors, respectively. After $6 \mathrm{~h}$, the conditional medium was collected and samples were prepared in non-reducing sample buffer and separated using SDS-PAGE gels containing 1\% gelatine (Sigma-Aldrich Inc.). After renaturing for $1 \mathrm{~h}$ at room temperature in washing buffer containing $2.5 \%$ Triton X-100 and $0.02 \% \mathrm{NaN}_{3}$, the gels were then incubated at $37^{\circ} \mathrm{C}$ in incubation buffer for $36 \mathrm{~h}$. Following incubation, the gels were stained with Coomassie blue for $1 \mathrm{~h}$ and washed in destaining buffer for another $1 \mathrm{~h}$. The gels were analysed using densitometry.

Statistical analysis. Statistical analysis was performed using SPSS18 (SPSS Inc., Chicago, IL, USA). IHC data were crosstabulated and a $\chi^{2}$ test was performed. The association of staining for WISP-1, WISP-2 and WISP-3 in GCs with patient survival was evaluated using life tables constructed from survival data with Kaplan-Meier plots and analysed using log-rank statistics. Overall survival was measured from date of initial surgery to date of death, counting death from any cause as the end point, or the last date of information as the end point if no event was documented. The association of the expression of WISPs and EMT markers was analysed using Spearman Rank Order Correlation analysis. Other data were analysed using Student's $t$-test for normally distributed data and Mann-Whitney $U$-test for non-normally distributed data. Each assay was performed at least three times. $P$-value $<0.05$ was considered statistically significant.

\section{RESULTS}

Expression of WISPs mRNAs, proteins and EMT markers in gastric tissues. When analysed by Q-RT-PCR, WISP-2 transcripts showed a higher level in tumours than in normal tissues $(P=0.0028)$ but WISP-1 and WISP-3 showed no differences ( $P=0.0642$ and $P=0.9076$, respectively). However, levels of the WISP-1 were highly expressed in tumours of patients without distant metastasis at diagnosis than those with $(P=0.0168)$. Levels of the WISP-2 transcript were found significantly higher in TNM1 and TNM2 stage tumours $(P=0.0249)$ than in TNM3 and TNM4 stages and also higher in $\mathrm{T} 1$ and $\mathrm{T} 2$ than in $\mathrm{T} 3$ and $\mathrm{T} 4$ 

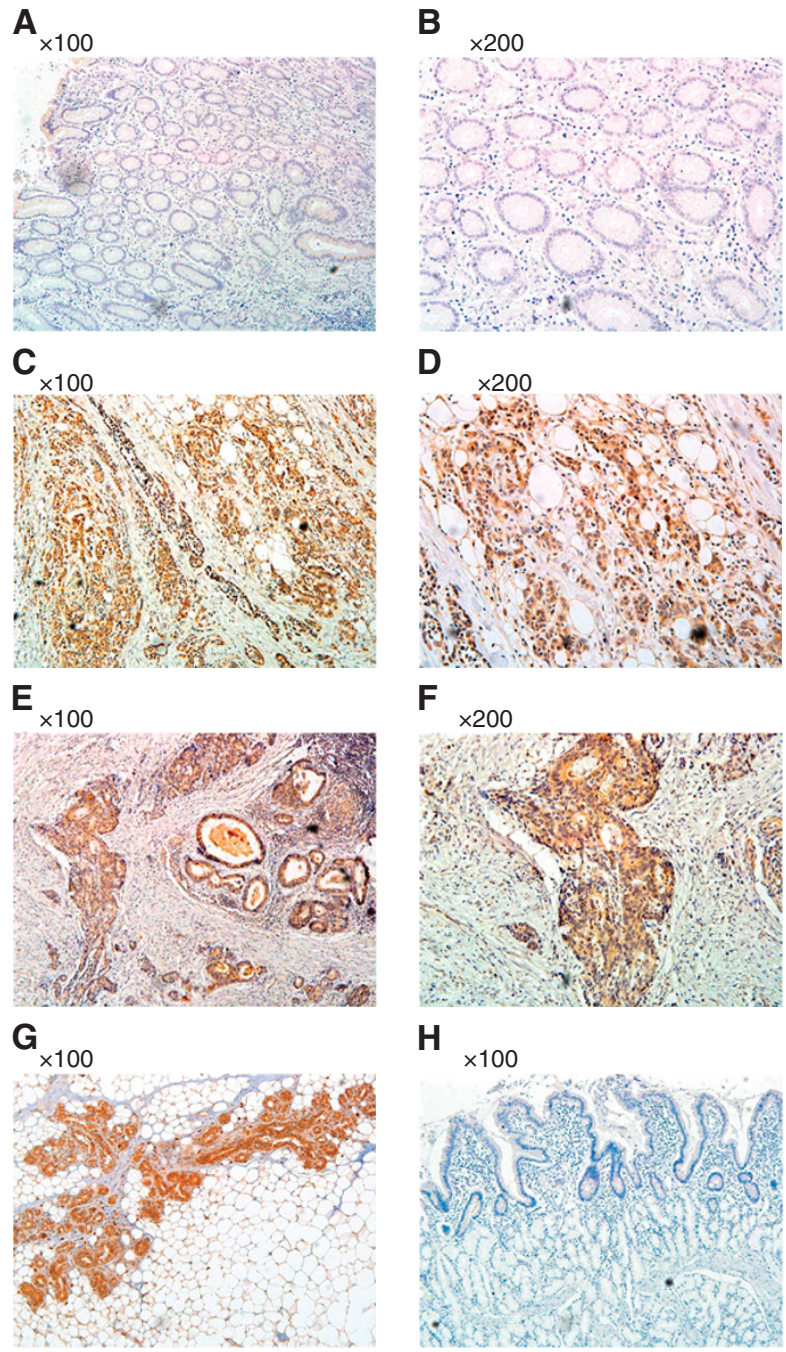

H $\times 100$
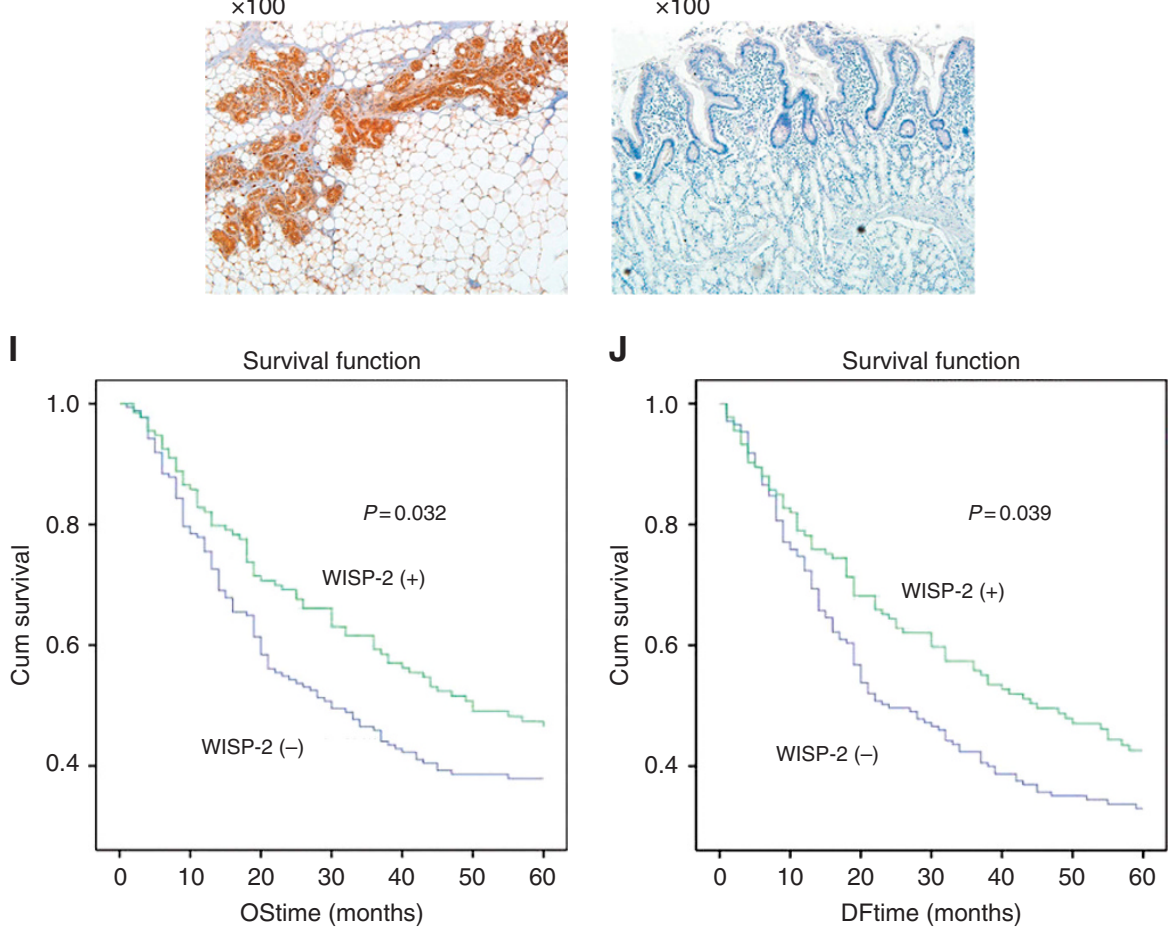

Figure 1. WISP-2 protein expression in primary gastric cancer and Kaplan-Meier survival curve for WISP-2 expression in gastric cancer tissues. In gastric cancer, WISP-2 protein was immunoreactive in the cytoplasm of malignant cells. The intensity of WISP-2 immunoreactivity was remarkably higher in primary gastric carcinoma when compared with matched normal mucosa. (A and B) Images of WISP-2 staining in normal gastric mucosa showed absent or weak cytoplasmic reactivity. (C and D) Images of WISP-2 staining in diffuse gastric cancer and ( $E$ and $\mathbf{F}$ ) in adenocarcinoma. (G) Positive control in breast epithelium, and (H) negative control using PBS as primary antibody in normal gastric mucosa. (I) Kaplan-Meier survival analysis displaying relationship between the transcript levels of WISP-2 and overall survival, WISP-2 $(+)$ represents the patients with higher expression of WISP-2 $(N=174)$. WISP-2 $(-)$ represents the patients with lower expression WISP-2 $(N=173)$. (J) Kaplan-Meier survival analysis displaying the relationship between the transcript levels of WISP-2 and disease-free survival. WISP-2 $(+)$ represents the patients with higher expression of WISP-2 ( $N=133)$, WISP-2 $(-)$ represents the patients with lower expression of WISP-2 $(N=171)$. WISP-2 expression is positively correlated with the survival of gastric cancer patients, either in overall survival or in disease-free survival $(P<0.05$, respectively). 
$(P=0.1817)$; higher in node-negative than in node-positive tumours $(P=0.128)$; higher in tumours without distant metastasis than those with $(P=0.39)$, and much higher in the patients alive than in those who died before the follow-up end time $(P=0.1698)$, although without statistical significance (see Table 1 for details). Of the study cohort, 316 tumour samples had matched normal tissues. We also analysed the tumour-to-normal ratio of the respective matched paired of samples. The tumour/normal ratio also showed significant links to the aforementioned clinicopathological parameters, although in a contrasting manner owing to how that ratio was calculated (Supplementary Table 2).

Expression levels of WISP proteins were analysed using immunohistochemical method. All three proteins were found to be located in the cytoplasmic region. Shown in Figure 1 are representative images for WISP-2, in which the protein staining in normal gastric tissues was largely negative (Figure $1 \mathrm{~A}$ and $\mathrm{B}$ ). In a clear contrast, the staining in gastric tumour tissues was highly positive and was clearly cytoplasmic. Semiquantitative analyses have shown that in line with Q-PCR findings, no difference was seen with WISP1 and WISP3. In addition, higher proportion of WISP2-positive staining was seen in well and moderately differentiated tumours than seen in poorly differentiated tumours, namely 23 out of 37 (62\%) of well/moderately differentiated tumours showing positive WISP-2 protein staining, compared with 58 out of $140(41 \%)$ positive staining in poorly differentiated tumours $(P=0.024$; Figure 1 and Table 2). Using Kaplan-Meier plot and log rank test, WISP-2 was found to be positively correlated with overall survival and disease-free survival of GC patients, namely patients with WISP-2-positive tumours having a longer overall survival $(P=0.032$, vs with WISP-2-negative tumours) and a longer disease-free survival $(P=0.039$ vs with negative tumours; Figure 1I and J).
Slug and Twist transcripts were higher in tumours than in normal tissues $(P=0.015$ and $P<0.0001$, respectively), whereas E-cadherin expression decreased in the tumour tissues compared with the normal tissues $(P<0.0001)$. The markers individually did not appear to be significantly correlated with the histological type or other parameters. However, the trio of the markers, namely, E-cadherin, Slug and Twist were significantly correlated with the incidence-free survival ( $P=0.005)$ and overall survival $(P=0.008)$, based on the KaplanMeier survival model (Table 3). Likewise, patients with the trio EMT marker abnormalities had a lower five-year survival rate. Using Spearman Rank Order Correlation analysis, it was found that WISP-2 expression was positively correlated with the expression of WISP-3 $(r=0.476, P<0.001)$ and WISP-1 $(r=0.244, P<0.001)$, but inversely with the expression of Twist $(r=-0.295, P<0.001)$ and Slug $(r=-0.229, P<0.001)$ in paired samples.

WISP-2 kd affected the growth, adhesiveness, invasiveness and motility of GC cells. To examine the function of WISP-2 in GC cells, we established WISP-2 kd sublines from two GC cell lines (AGS WISP-2 kd and HGC27 WISP-2 kd for abbreviation). Control cell lines were those transfected with the pEF6 control vector (AGS pEF and HGC27 $\mathrm{pEF}$ ) and with a plasmid in which the ribozyme transgene was inserted in a wrong direction (namely sense direction). Cells were named as AGS sense plasmid control and HGC27 sense plasmid control. Both sublines (AGS WISP-2 kd and HGC27 WISP-2 kd) showed high efficiency of WISP-2 kd (Figure 2A-D). Neither the vector control nor the sense plasmid control resulted in loss of WISP2 (Figure 2). Stable transfection and transient transfection using the anti-WISP2 ribozyme transgene resulted in a similar loss of WISP-2 in both cells.

As shown in Figure 2E, increased cell growth was observed in both AGS WISP-2 kd and HGC27 WISP-2 kd cells compared with

Table 2. Association of WISP-1, WISP-2 and WISP-3 protein expression with clinicolpathological parameters in gastric cancer patients

\begin{tabular}{|c|c|c|c|c|c|c|c|c|c|c|c|c|}
\hline \multirow[b]{2}{*}{ Variables } & \multicolumn{4}{|c|}{ WISP-1 expression } & \multicolumn{4}{|c|}{ WISP-2 expression } & \multicolumn{4}{|c|}{ WISP-3 expression } \\
\hline & Cases & $\begin{array}{l}\text { WISP-1 - } \\
(n=123)\end{array}$ & \begin{tabular}{|c|} 
WISP-1 \\
$(n=114)$
\end{tabular} & $P$ & Cases & $\begin{array}{l}\text { WISP-2 - } \\
(n=128)\end{array}$ & $\begin{array}{l}\text { WISP-2+ } \\
(n=101)\end{array}$ & $P$ & Cases & $\begin{array}{c}\text { WISP-3 - } \\
(n=56)\end{array}$ & $\begin{array}{c}\text { WISP-3+ } \\
(n=185)\end{array}$ & $P$ \\
\hline \multicolumn{13}{|l|}{ Gender } \\
\hline Male & 172 & 89 & 83 & & 161 & 87 & 74 & & 174 & 39 & 135 & 0.626 \\
\hline Female & 65 & 34 & 31 & 0.938 & 68 & 41 & 27 & 0.384 & 67 & 17 & 50 & \\
\hline \multicolumn{13}{|l|}{ Age (years) } \\
\hline$\leqslant 60$ & 114 & 60 & 54 & & 114 & 67 & 47 & & 117 & 31 & 86 & 0.198 \\
\hline$>60$ & 122 & 61 & 61 & 0.686 & 113 & 59 & 54 & 0.32 & 123 & 24 & 99 & \\
\hline \multicolumn{13}{|c|}{ Depth of wall invasion } \\
\hline $\mathrm{T} 1+\mathrm{T} 2$ & 35 & 20 & 15 & & 35 & 20 & 15 & & 38 & 7 & 31 & 0.499 \\
\hline $\mathrm{T} 3+\mathrm{T} 4$ & 190 & 95 & 95 & 0.437 & 182 & 102 & 80 & 0.904 & 192 & 45 & 147 & \\
\hline \multicolumn{13}{|l|}{ Differentiation } \\
\hline Well and moderate & 40 & 16 & 24 & & 37 & 14 & 23 & & 41 & 8 & 33 & 0.562 \\
\hline Poorly & 146 & 80 & 66 & 0.097 & 140 & 82 & 58 & $0.024^{\star}$ & 147 & 35 & 112 & \\
\hline \multicolumn{13}{|c|}{ Lymph node metastasis } \\
\hline Negative & 46 & 26 & 20 & & 47 & 30 & 17 & & 45 & 31 & 14 & 0.307 \\
\hline Positive & 173 & 85 & 88 & 0.373 & 164 & 88 & 76 & 0.216 & 121 & 65 & 56 & \\
\hline \multicolumn{13}{|l|}{ Liver metastasis } \\
\hline MO & 185 & 94 & 91 & & 179 & 97 & 82 & & 190 & 41 & 149 & 0.415 \\
\hline M1 & 35 & 17 & 18 & 0.808 & 33 & 22 & 11 & 0.184 & 36 & 10 & 26 & \\
\hline \multicolumn{13}{|l|}{ Vascular invasion } \\
\hline$V(-)$ & 126 & 69 & 57 & & 121 & 75 & 46 & & 126 & 31 & 95 & 0.651 \\
\hline$V(+)$ & 109 & 53 & 56 & 0.348 & 106 & 53 & 53 & 0.069 & 113 & 25 & 88 & \\
\hline \multicolumn{13}{|l|}{ TNM stages } \\
\hline$I+I I$ & 72 & 39 & 33 & 0.441 & 72 & 43 & 29 & & 78 & 17 & 61 & 0.8 \\
\hline$I I I+I V$ & 144 & 70 & 74 & & 137 & 74 & 63 & 0.43 & 146 & 34 & 112 & \\
\hline
\end{tabular}


Table 3. Expression of the transcript of EMT markers Twist, Slug and E-cadherin in paired gastric tissues $(n=189)$

\begin{tabular}{|l|c|c|c|}
\hline & E-cadherin & Twist & Slug \\
\hline Normal tissues $^{\mathbf{a}}$ & $39(3,284)$ & $0.056(0.027,0.081)$ & $4.3(0.2,35.3)$ \\
\hline Tumour tissues $^{\mathbf{a}}$ & $3(0,53)$ & $7.98(3.99,32.3)$ & $7.8(1.9,41.5)$ \\
\hline$P$ value $^{\mathbf{b}}$ & $P<0.0001$ & $P<0.0001$ & $P=0.0015$ \\
\hline Pbb & &
\end{tabular}

Abbreviation: $\mathrm{EMT}=$ epithelial-mesenchymal transition

${ }^{a^{a}}$ Shown are median (IQR) level of the transcript (copies per $\left.\mu \mathrm{l}\right)$.

by Mann-Whitney U-test.

their pEF countparts $(13.199 \pm 5.63$ vs $23.961 \pm 4.11, P<0.001$ and $15.939 \pm 4.95 \pm 2.51$ vs $27.635, P<0.001$, respectively). WISP-2 kd resulted in a dramatic increase of invasiveness of AGS $(133.58 \pm 18.8$ vs $207.36 \pm 19.71, \quad P<0.01)$ and HGC27 $(88.66 \pm 27.43$ vs $153.66 \pm 10.01, P<0.01)$ cells (Figure $2 \mathrm{~F})$ compared with controls. WISP-2kd also resulted in an increase in motility of AGS $(105.49 \pm 22.34$ vs $145.16 \pm 18.66, P<0.01)$ and HGC27 $(127.53 \pm 32.76$ vs $161.39 \pm 40.38, P<0.05)$ cells (data not shown). However, kd of WISP-2 exhibited a relatively weak impact on cell matrix adhesion. The number of cells adherent to Matrigel over a culture period of $45 \mathrm{~min}$ was slightly decreased in both AGS and HGC27 WISP-2 kd cells (Figure 2G, $P>0.05$, respectively).

Cell adhesion was also analysed using ECIS. After $40 \mathrm{~min}$ of adhesion, there was no significant difference in the resistance between WISP-2 kd and pEF controls in both cells (Figure $2 \mathrm{H}$, $P>0.05$, respectively). After treatment with small PLC- $\gamma$ inhibitor (STK870702, Vitas-M Laboratory Ltd; $1.12 \mu \mathrm{M}$ ) and a genetic PLC inhibitor (U73122, Tocris Bioscience; $0.75 \mu \mathrm{M}$ ), the motility of HGC27 WISP-2 kd decreased compared with control cells $(P<0.05)$. A significant decrease was also observed in HGC27 WISP-2 kd cells treated with JNKII $(1.5 \mu \mathrm{M})$. However, FAK small inhibitors $(1.5 \mu \mathrm{M})$ and N-WASP small inhibitors $(1.5 \mu \mathrm{M}$, data not shown) did not change the effect on both cell lines $(P>0.05$; Figure $3 \mathrm{~A} \sim \mathrm{D}$ ).

WISP-2 kd resulted in increased enzymatic activity of MMPs via JNK and/or ERK pathways. MMPs are key proteins implicated in ECM remodelling and degradation by metastatic cells (Coussens et al, 2002). WISP-2 kd resulted in an upregulation of MMP9 in AGS WISP-2 kd cells, and MMP9 and MMP2 in HGC27WISP-2 $\mathrm{kd}$ cells, which were consistent with increased invasiveness in both cells. We further treated both cells with $200 \mathrm{nM}$ JNKII and ERKII small inhibitor. The elevated MMP9 activity in AGS WISP-2 kd cells was reduced after treatment with ERK and JNK inhibitors. However, the elevated MMP9 and MMP2 activity in HGC27 WISP-2 kd cells were reduced only by JNK inhibitor, but not by ERK inhibitor (Figure 4A and B).

WISP-2 kd influenced invasiveness of AGS cells treated with MMP inhibitors. Figure 4C and D shows AGS cells with WISP-2 $\mathrm{kd}$ after treatment with MMP9 inhibitor (Marimastat), which significantly decreased invasiveness $(P=0.025)$ compared with AGS WISP-2 kd cells with no treatment. The group treated with ARP100 did not demonstrate a significant change on cell invasion compared with the control group $(P>0.05)$.

Expression of EMT markers in cell lines. The results showed that after WISP-2 kd, there was a significant decrease in expression of E-cadherin $(P<0.05)$ and an increase on the expression of Twist, $\mathrm{N}$-cadherin and Vimentin $(P<0.01, \quad P<0.05$ and $P<0.01$, respectively). Expression of Slug was found to have no statistical difference between both cells lines. Representative images of Q-RTPCR and RT-PCR verification of the expression of E-cadherin, $\mathrm{N}$-cadherin, Twist, Slug and Vimentin in cell lines are shown in Figure $4 \mathrm{E}$ and $\mathrm{F}$.

\section{DISCUSSION}

Expression of WISPs are widely observed in solid tumours including GC. WISP family members have been shown to play multiple roles in a number of pathophysiological processes, including cell proliferation, adhesion, invasiveness, wound healing, ECM regulation and EMT. A number of clinical studies have shown that WISP family members are deregulated in a variety of solid tumours and their metastases (Zoubine et al, 2001; Banerjee et al, 2003; Russo and Castellot, 2010; Banerjee and Banerjee, 2012). However, the cellular functions of WISPs are not yet fully eluciated. Our previous studies have suggested that there may be different effects of WISP-1 and WISP-2 on tumour progression in different tumour types. In colorectal cancer, WISP-1 appears to be act as a factor stimulating aggressiveness and WISP-2 as a tumour suppressor, whereas in breast cancer, WISP-1 acts as tumour suppressor and WISP-2 stimulates tumour aggressiveness. The role of WISP-3 has not been fully determined in either colorectal or breast cancer (Davies et al, 2007, 2010).

WISP-2 is the most studied of the WISP molecules with different roles in tumour progression in different tissue types. Higher WISP-2 expression has been detected in less aggressive human breast cancer cells (that is, MCF-7 and ZR-75-1). Moderately aggressive breast cancer cell lines (that is, SKBR-3) express a basal level of WISP-2, whereas WISP-2 expression is not detected in the highly aggressive breast cancer cell line MDA-MB231 (Banerjee et al, 2005; Sengupta et al, 2006). Growing experimental evidence demonstrates that WISP-2 has an antiinvasive role in breast carcinogenesis through controlling adhesion and cell motility (Banerjee et al, 2008; Fritah et al, 2008).

Nonetheless, the contrasting correlations between the clinical/ pathological parameters and WISP-2 levels $v s$ with WISP2 tumour/ normal ratio are an interesting observation. Although WISP2 transcript levels were high in cancer tissues and low in normal gastric tissues and one would expect that the WISP2 levels in cancer and the tumour/normal ratio of the transcript to be in line with each other, the experimental data, however, indicated otherwise. One possibility is that the levels of WISP2 transcript in a tumour are independent of that seen in the counterpart normal tissue. Together with the in vitro data which showed a tumour-suppressive role of WISP2 in GC cell lines, it is suggested that the levels of WISP2 transcript in tumours, rather than the tumour-to-normal ratio is an more appropriate reflection of the role of WISP2 in GC.

This study has provided new data that expression of WISP-2 at mRNA and protein levels are also aberrant in GC. Positive WISP-2 protein staining in GC are associated with a longer survival of the patients, and with differentiation of GC cells in gastric tumour, namely, 23 out of $37(62 \%)$ positively stained in well/moderate differentiated tumours $v s 58$ out of 140 (41\%) in poorly differentiated tumours. Thus, in line with the reports in breast cancer, the current study would support the hypothesis that WISP2 is a candidate biomarker for disease progression in human GC.

Expression of WISP-2 and EMT in GC. Previous studies have suggested that WISP-2 is able to reverse some features of the EMT process (Dhar et al, 2007; Banerjee et al, 2008). It has also been shown to recover the function of mutant p53 (Dhar et al, 2008). These mechanisms are important in the invasion and metastatic growth of breast cancer cells. This study is the first to record the association of WISP mRNA and proteins expression with clinicolpathological parameters and outcome in GC patients as well as the association with those of EMT markers. Here we show that WISP-2, but not WISP-1 or WISP-3, was inversely correlated with two of the EMT markers namely Twist and Slug. Twist and Slug are transcription EMT markers, the activation of which has 
A

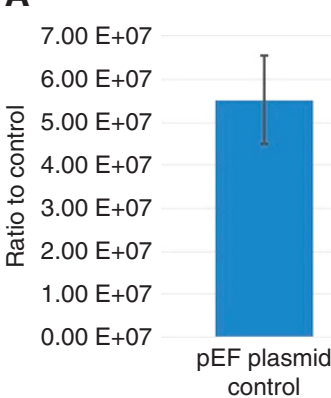

AGS

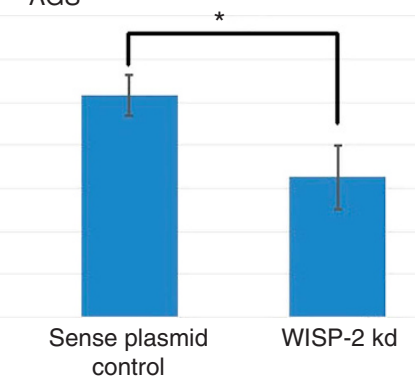

C

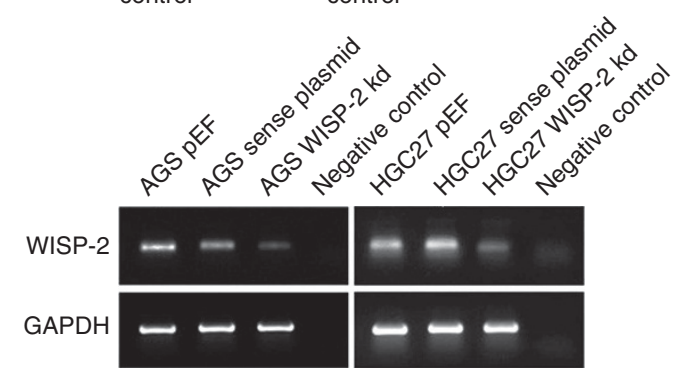

$\mathbf{E}$
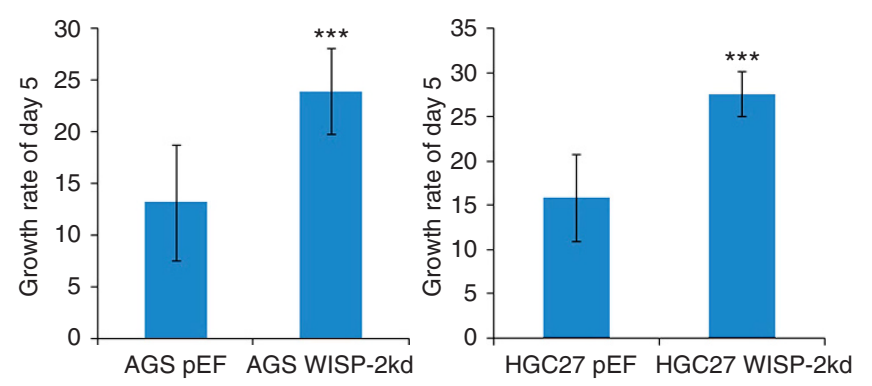

G
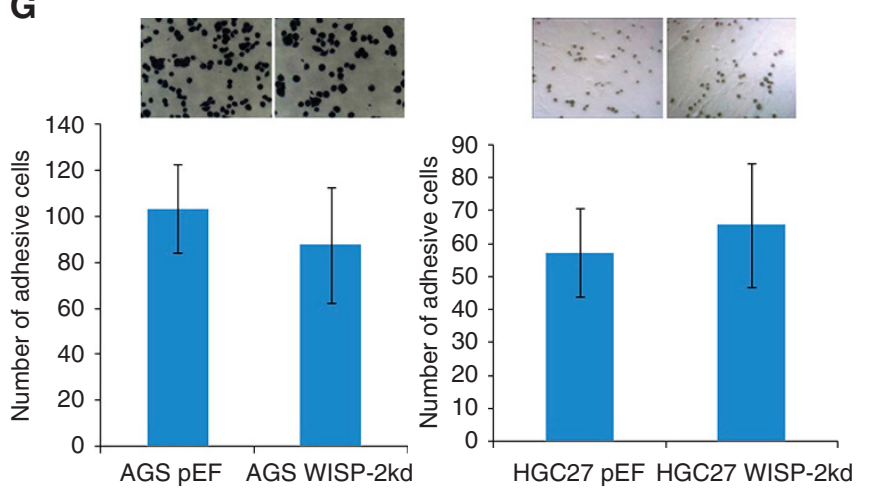

B
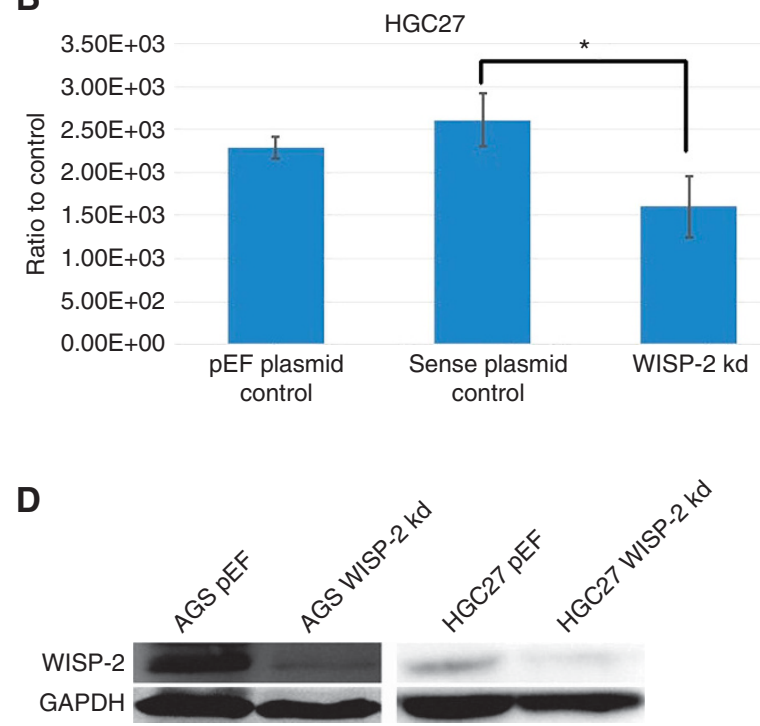

$\mathbf{F}$

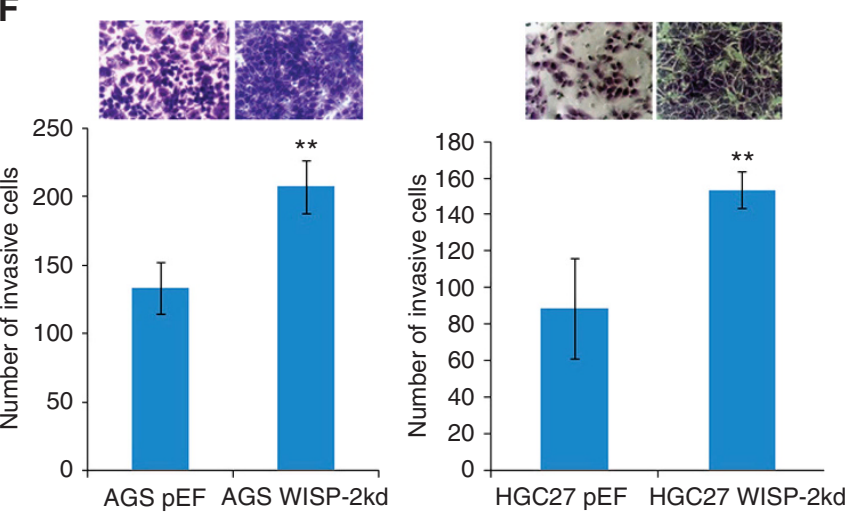

H
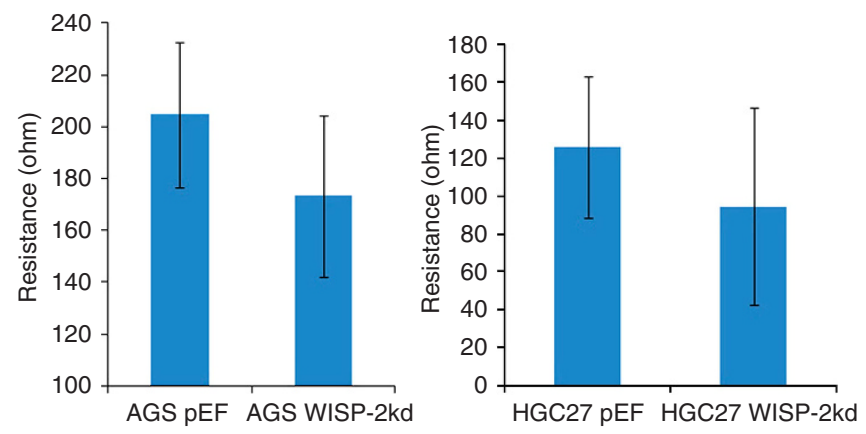

Figure 2. Verification of knockdown (kd) of WISP-2 in AGS and HGC27 cells. (A and B) Quantitative real-time PCR showing WISP-2 mRNA volume of five repeats, which was normalised against corresponding internal control (GAPDH). WISP-2 expression was decreased in AGS WISP-2 kd and HGC27 WISP-2 kd cells compared with corresponding pEF plasmid control cells and anti-sense plasmid control cells ( $\left.{ }^{\star} P<0.05\right)$. (C) RT-PCR showing reduced levels of WISP-2 mRNA in AGS WISP-2 kd and HGC27 WISP-2 kd cells compared with corresponding pEF plasmid control cells and sense plasmid control cells. (D) Decreased levels of WISP-2 protein (MW: 26KD) in AGS WISP-2 kd and HGC27 kd cells compared with corresponding pEF control cells are shown. (E left) After 5 days' incubation, there was a significant increase in the AGS WISP-2 kd cells compared with the pEF controls and (E right) increase in the HGC27 WISP-2 kd cells compared with the pEF controls (*** $P<0.001)$. (F) Knockdown of WISP-2 caused a significant increase in the invasiveness of AGS WISP-2 kd cells compared with the AGS pEF cells (left) and HGC27 WISP-2 kd cells compared with the HGC27 pEF cells (right) (**P<0.01; right). (G) Representative images of cells following staining: after 45 min' incubation on an artificial Matrigel basement membrane, the difference of the numbers of adherent cells was not significant in both AGS and HGC27 groups. (H) ECIS results also showed that there were no significant differences in adhesiveness in the first 45 min of knockdown groups than in pEF controls in AGS and HGC27 cells ( $P>0.05$, respectively). 
A

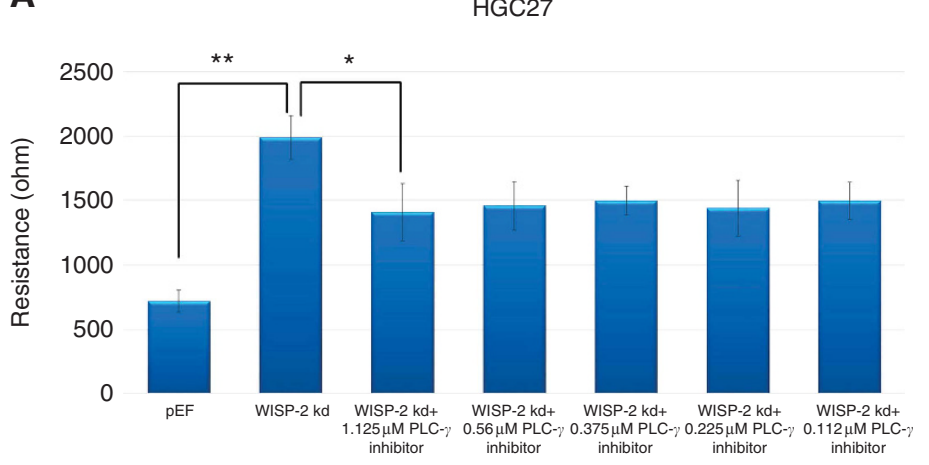

C

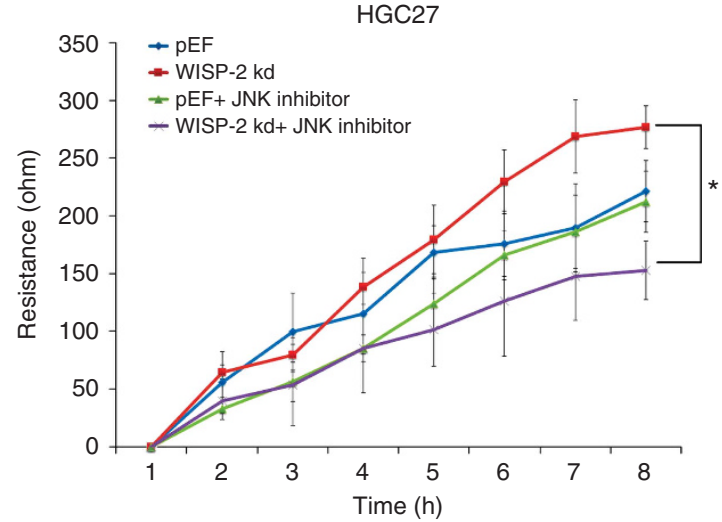

B

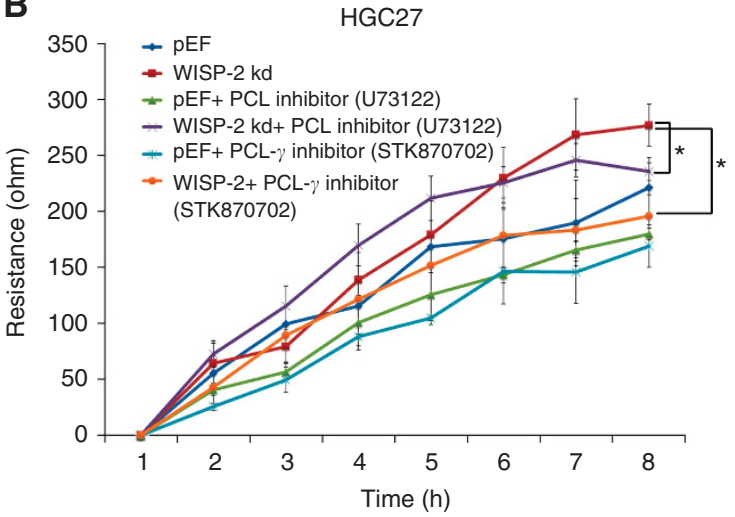

D

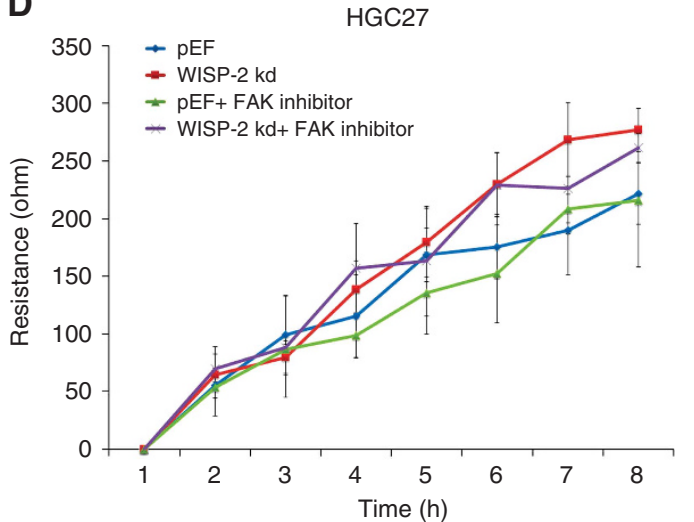

Figure 3. The effect of WISP-2 knockdown on the motility of AGS cells and the involvement of PLC- $\gamma$, JNK and FAK pathway. (A) ECIS results showed that when treated with PLC- $\gamma$ inhibitor STK870702, the migration distance of HGC27 WISP-2 kd cells (Resistance) decreased significantly as the concentration increased from 0.112 to $1.125 \mu \mathrm{M}$. PLC- $\gamma$ inhibitor did not change the migration distance of pEF cells significantly at any concentrations $\left({ }^{*} P<0.05,{ }^{*} P<0.01\right)$. (B-D) Knockdown of WISP-2 in HGC27 cells resulted in increased cell motility via PLC- $\gamma(\mathbf{B})$ and JNK (C) pathways. Incubation of HGC27 WISP-2 kd cells with both $0.75 \mu \mathrm{M}$ (U73122) and 1.125 $\mu \mathrm{M}$ (STK870702) of PLC- $\gamma$ small inhibitors and $1.5 \mu \mathrm{M}$ of JNK small inhibitor diminished such effect. (D) Incubation of HGC27 WISP-2 kd cells with FAK small inhibitor had no effect on cell motility.

been shown to suppress the expression of E-cadherin (Yang et al, 2004; Lombaerts et al, 2006; Vesuna et al, 2008). We were the first to report a link between overexpression of Twist and Slug and long-term survival in patients with breast cancer (Martin et al, 2005). Slug has been reported to be overexpressed in GC similar to that seen in the present study (Rosivatz et al, 2002; Castro Alves et al, 2007). Thus, the observations on the clinical cohort suggest that low levels of WISP-2 are linked to raised Twist and Slug, which in turn lead to a reduction in E-cadherin expression.

Further supporting information for the WISP-2/EMT link comes from the in vitro experiments of this study. At the cellular level, knockdown of WISP-2, in both AGS and HGC27 cell lines, led to increased cell proliferation, motility and invasiveness, hallmarks of EMT in cells including cancer cells. At transcription and translation levels, WISP-2 knockdown in GC cells triggers an upregulation of Twist, N-cadherin and Vimentin, markers of mesenchymal genotype (Zeisberg and Neilson, 2009).

Collectively, these results suggest that WISP-2 is an EMT regulator and that WISP-2 expression supports an epithelial phenotype. This link has provided a plausible explanation for WISP-2 to be potential suppressor of EMT (or an inducer of MET). The suggested link and interaction pathway are summarised in Figure 5.

WISP-2 and expression of MMPs, a role for the JNK pathway. Suppression of WISP-2 expression leads to the upregulation of the matrix MMPs, MMP2 and MMP9, which are often found to be highly expressed in the invasive breast cancer phenotype (Banerjee et al, 2008). The expression of MMP-1, MMP-2, MMP-9 and
MMP-13 has been shown to be linked to the aggressiveness of tumours and their expression is mediated by p38 in various tissues including prostate, breast, bladder, liver and skin keratinocyte cell lines. Several reports have shown that MMP9 is upregulated by the ERK signalling pathway in different human cells (Li et al, 2003). However, the mechanism by which WISP-2 deficiency enhances the invasiveness of cancer cells has not been elucidated and remains poorly understood (Vandooren et al, 2013). In the present study, we have discovered that WISP-2 may suppress the expression of MMPs as well as activities of MMP2 and MMP9 in GC cells. Our study also describes a role for JNK and ERK in this regulation, partly owing to the observation that treatment with JNKII and ERKII small inhibitors blocked the effects seen by knocking down WISP2, indicating that the JNK pathway is suppressed by WISP-2. Our results echo a recent report in which Twist has been linked to the expression of MMP1 (Weiss et al, 2012). It is thus indicated that loss of WISP-2 results in activation of MMPs in cancer cells (Figure 5).

WISP-2 has an intimate link with phospholipase $\mathrm{C}-\gamma$ and JNKmediated cell functions. Phospholipase $\mathrm{C}-\gamma$ is a critical molecule in growth factor-dependent signalling transduction, and its expression is related with cell motility and tumorigenesis (Jones et al, 2005; Davies et al, 2008; Zhang et al, 2011). PLC $\gamma 1$ activation induces hydrolysis of phosphatidylinositol-4,5-bisphosphate to form the second messengers diacylglycerol and inositol-1,4,5trisphosphate, which in turn activate protein kinase $\mathrm{C}$ and intracellular calcium mobilisation, respectively. Through both events, PLC $\gamma 1$ is involved in a number of physiological processes 
A

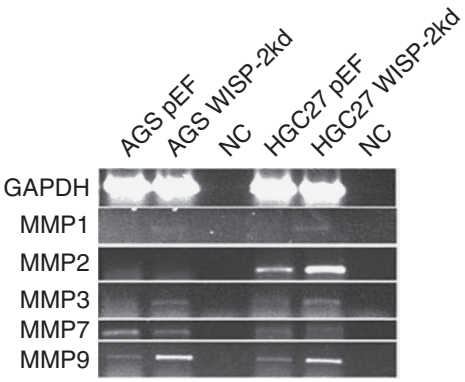

C

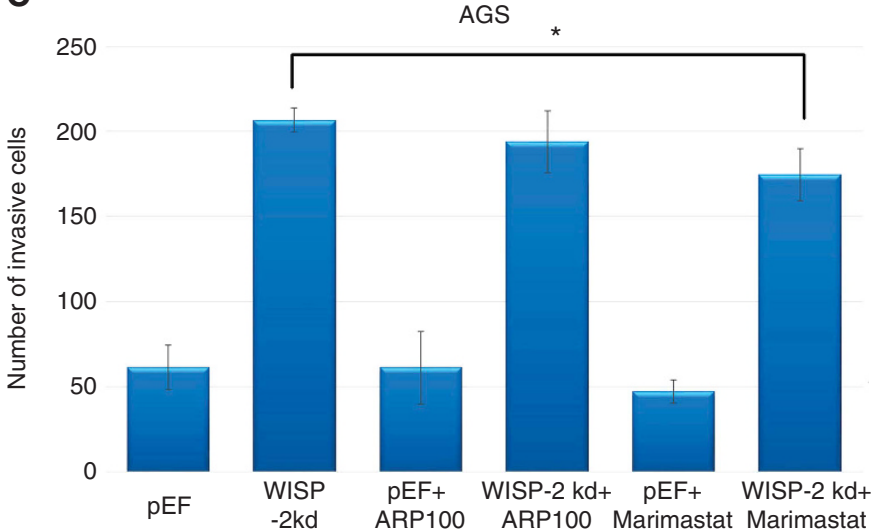

E

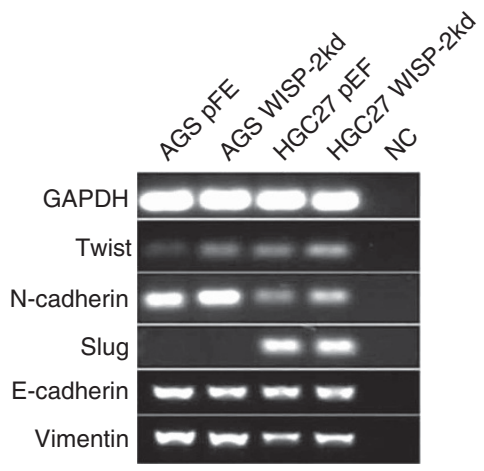

B

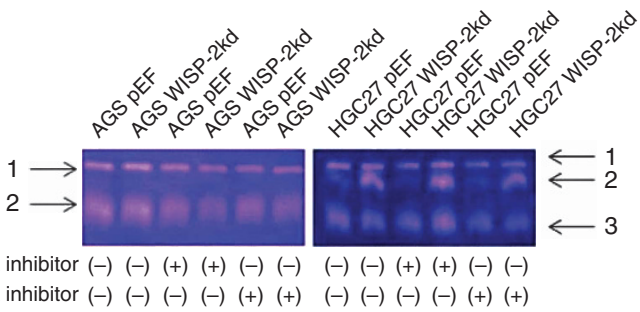

D

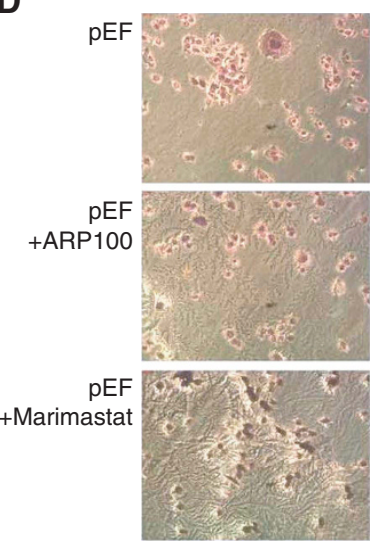

AGS

WISP-2 kd

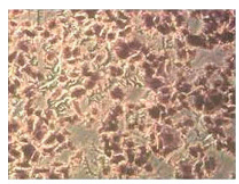

WISP-2 kd +ARP100

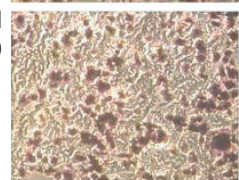

WISP-2 kd +Marimastat

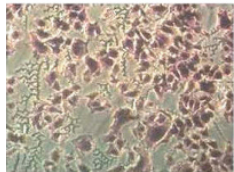

F
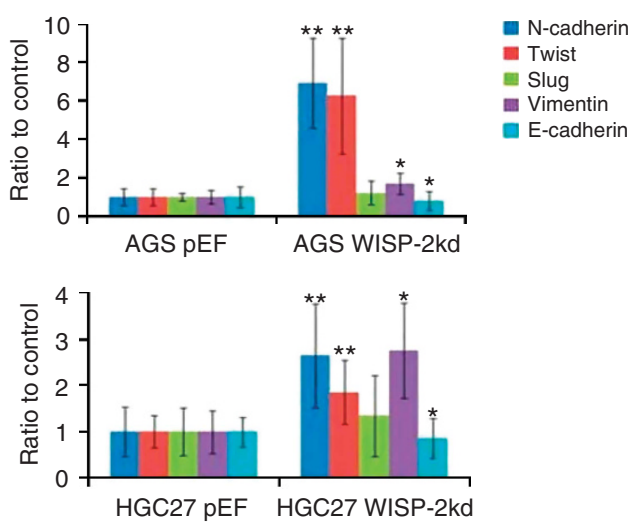

Figure 4. MMP9 expression and activity and EMT markers change in AGS and HGC27 sublines. (A) RT-PCR showed the expression of MMP1, 2, 3 and 9 was increased in HGC27 WISP-2 kd cells and there was no obvious difference of MMP7 compared with controls. Expression of MMP7 was downregulated in AGS WISP-2 kd cells, MMP1, 2, 3 and 9 were upregulated, however, there was no obvious expression of MMP2 in AGS WISP-2 kd cells compared with controls. (B) Gelatine zymography indicated the reduced emzyme activity of MMP9 in AGS WISP-2 kd cells treated with ERK and JNK inhibitors and reduced MMP9/2 in HGC27 WISP-2 kd cells treated with JNK inhibitors. 1: pro-MMP9, 2: MMP9 and 3: MMP2. (C) Knockdown of WISP-2 caused a significant increase in the invasiveness of AGS WISP-2 kd cells treated with MMP9 inhibitor (Marimastat) compared with the AGS WISP-2 kd cells without treatment $\left({ }^{*} P<0.05\right)$. (D) Representative images of cells following staining: after $72 h^{\prime}$ incubation on an artificial Matrigel basement membrane, the difference of the numbers of invasive cells was significantly observed in groups treated with MMP9 inhibitor compared with the control group. (E and F) EMT marker expression differences after WISP-2 knockdown in AGS and HGC27 cells. Expression levels of Twist, $\mathrm{N}$-cadherin and Vimentin were increased and E-cadherin were decreased. And there was no difference in Slug expression.

including cell proliferation, migration, survival and death (Lattanzio et al, 2013). It has also been reported that individually or combined inhibition of PLC- $\gamma$ and c-Src could block EGFRmediated HNSCC cell invasion (Nozawa et al, 2008). The PLC- $\gamma$ inhibitor STK870702 impedes the DNA synthesis of the breast cancer cell lines investigated in the nanomolar range as a consequence of anti-proliferative activity. It has been shown that cell cycle arrest is instigated in the G2/M phases. Furthermore, morphology and motility were severely affected by STK870702 in the MDA-MB-231 breast tumour cell line (Leung et al, 2014). In our study, inhibition of PLC- $\gamma$ by STK870702 and a less specific inhibitor U73122 could block WISP-2 knockdown-mediated HGC27 cell migration, which suggests that WISP-2 may suppress HGC27 cell migration partly via suppressing the PLC- $\gamma$ pathway (Figure 5). However, the role of PLC- $\gamma$ in cancer is not entire clear. Although PLC- $\gamma$ has been indicated in the regulation of cell migration and in tumour progression in some case, some of the recent reports have shown that it can play a role in suppressing tumour growth. Capietto et al (2013) have reported that PLC- $\gamma 2$ deficiency would result in faster tumour growth, possibly by reducing the population of myeloid-derived suppressor cells, which in turn promote tumour growth. The authors argued that this is 


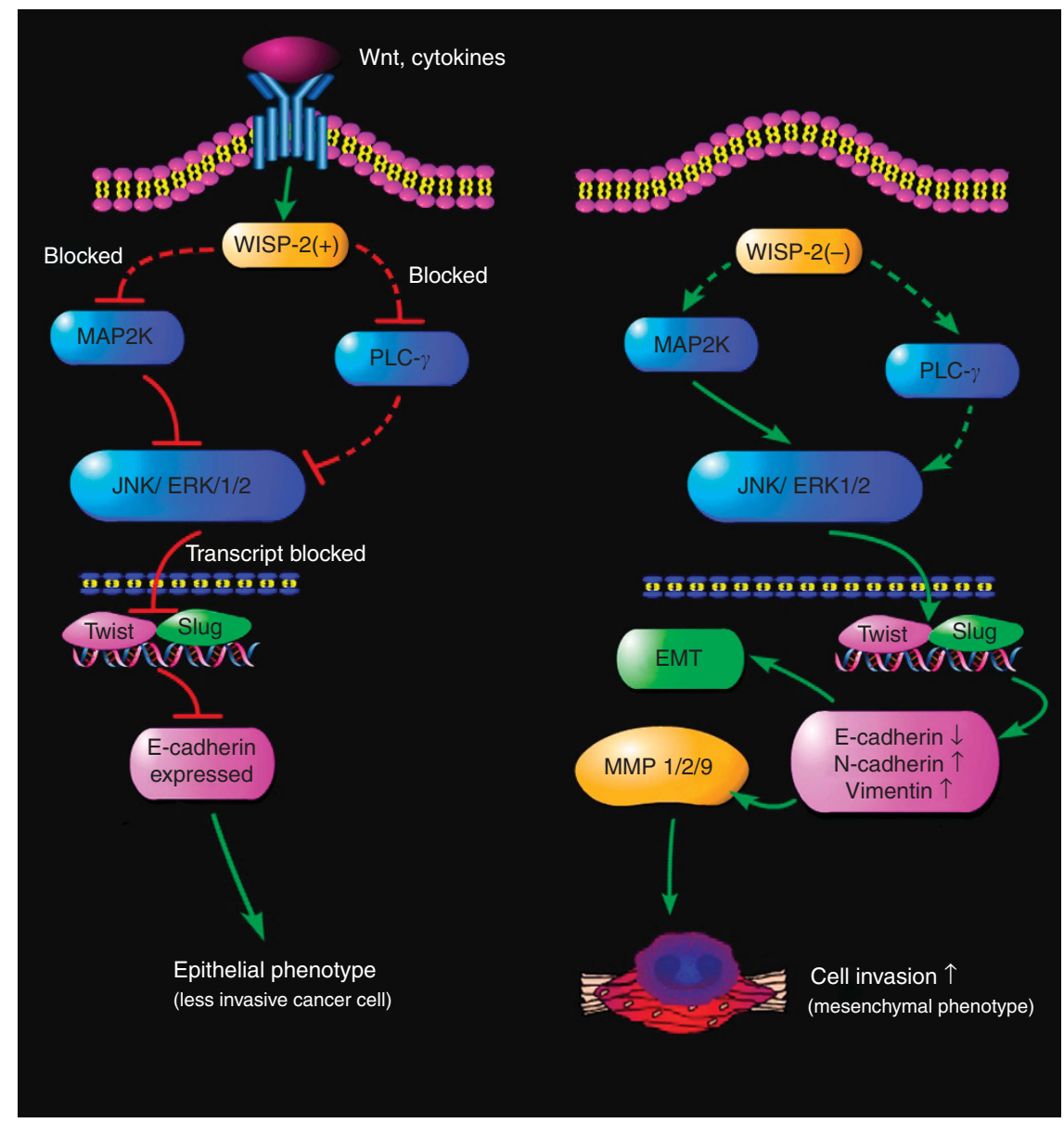

Figure 5. Suggested mechanism of action by WISP-2 in gastric cancer cells. In cells in which WISP2 is well expressed (possibly induced by Wnt proteins), it acts as an inhibitory mechanism to the ERK/JNK pathway and the PLC- $\gamma$ pathway, thus preventing, to some degree, the activation of transcription event for EMT regulating proteins and MMPs. However, in cells where WISP-2 is reduced/lost, the ERK/JNK pathway is activated, leading to the transcription activation of EMT transcription factors including Twist and Slug. This leads to the reduction of E-cadherin and molecules leading to EMT. Similarly, PLC- $\gamma$ and JNK activations lead to the activation of MMP synthesis. These two pathways collectively contribute to the increase in cellular migration and tissue invasion. Dash lines indicate where gaps exist and require further work.

likely due to a reduction of $\beta$-catenin after inducing PLC- $\gamma 2$ deficiency. Reduction of both PLC- $\gamma$ and $\beta$-catenin has been observed in the myeloid-derived suppressor cells in patients with cancer (Capietto et al, 2013). In addition, the link between PLC $\gamma$, cell migration and cell adhesion appears to have association with the balance and compensation between the isoforms of PLC $\gamma$ as well as choline metablism (Beloueche-Babari et al, 2009). Despite these evidence, one has to bear that the isoforms of PLC $\gamma$, namely PLC $\gamma 1$ and PLC $\gamma 2$, can have different and sometimes contrasting effect in different cells and cell models. Thus, the relationship between WISP-2 and PLC $\gamma$, its isoforms and indeed the role of PLC $\gamma$ in cancer would require further investigation. We are currently exploring the potential link between WISP2, $\beta$-catenin and PLC $\gamma$ in this connection.

Sengupta et al (2006) found that the upregulation of WISP-2 by phorbol ester is mediated through a complex protein kinase $\mathrm{C} \alpha$ MAPK/ERK and MAPK/JNK signalling pathway, which leads to growth stimulation of MCF-7 breast tumour cells. However, in our study, JNK may act as a downstream molecule of WISP-2 in the cytoplasm. JNK belongs to the JNK P38 MAP kinase pathway. In non-stimulated cells, JNK2 seems to mainly target $c$-Jun for degradation. However, in stimulated cells, JNK1 phosphorylates and stabilises $c$-Jun resulting in activation of transcription of the target genes. The effects of JNK small inhibitor on WISP-2 knockdown-mediated HGC27 cell migration indicate that WISP-2 may suppress HGC27 cell migration via suppressing JNK and its downstream pathway. However, the exact mechanism and other unknown interacting molecules involved in this effect require further investigation.

Overall, the current study suggests the clinical significance of WISP-2 in gastric tumour progression in that WISP-2 is positively correlated with the clinical features and the survival of the patients with GC. Moreover, this study unveiled a molecular mechanism of regulation of WISP-2 expression in GC metastasis, namely that WISP-2 is a critical negative regulator of growth, motility and invasion in GC cells via key signalling pathways involving JNK, ERK and PLC- $\gamma$, which lead to the regulation of the EMT process. Taken together, this study shows that WISP-2 is a potential tumour suppressor. It is plausible that the reactivation of WISP-2 into invasive/metastatic GCs alone or in combination of current therapeutic regimens may provide a unique alternative strategy to existing GC therapy.

\section{ACKNOWLEDGEMENTS}

We thank Cancer Research Wales, Ser Cymru Welsh Life Science Network and the Albert Hung Foundation for supporting our work. This project was also funded by the 'Young Scientific Elite Project of Educational Bureau, Inner Mongolia Autonomous Region, China, 2012' (No. NJYT-12-B21) and 'Great Project of the Affiliated Hospital of Inner Mongolia Medical University, 
China, 2013' (No. NYFY ZD 2012014), and by Natural Science Foundation of China (81374016) and Beijing Municipal Science and Technology Commission (D141100000414002).

\section{CONFLICT OF INTEREST}

The authors declare no conflict of interest.

\section{REFERENCES}

Banerjee S, Dhar G, Haque I, Kambhampati S, Mehta S, Sengupta K, Tawfik O, Phillips TA, Banerjee SK (2008) CCN5/WISP-2 expression in breast adenocarcinoma is associated with less frequent progression of the disease and suppresses the invasive phenotypes of tumor cells. Cancer Res 68: 7606-7612.

Banerjee S, Saxena N, Sengupta K, Tawfik O, Mayo MS, Banerjee SK (2003) WISP-2 gene in human breast cancer: estrogen and progesterone inducible expression and regulation of tumor cell proliferation. Neoplasia 5: 63-73.

Banerjee S, Sengupta K, Saxena NK, Dhar K, Banerjee SK (2005) Epidermal growth factor induces WISP-2/CCN5 expression in estrogen receptoralpha-positive breast tumor cells through multiple molecular cross-talks. Mol Cancer Res 3: 151-162.

Banerjee SK, Banerjee S (2012) CCN5/WISP-2: a micromanager of breast cancer progression. J Cell Commun Signal 6: 63-71.

Beloueche-Babari M, Joanna C, Peak JC, Jackson LE, Tiet MY, Leach MO, Eccles SA (2009) Changes in choline metabolism as potential biomarkers of phospholipase $\mathrm{C} \gamma 1$ inhibition in human prostate cancer cells. Mol Cancer Ther 8: 1305-1311.

Bork P (1993) The modular architecture of a new family of growth regulators related to connective tissue growth factor. FEBS Lett 327: 125-130.

Brigstock DR (2003) The CCN family: a new stimulus package. J Endocrinol 178: $169-175$.

Calvisi DF, Conner EA, Ladu S, Lemmer ER, Factor VM, Thorgeirsson SS (2005) Activation of the canonical Wnt/beta-catenin pathway confers growth advantages in c-Myc/E2F1 transgenic mouse model of liver cancer. J Hepatol 42: 842-849.

Capietto AH, Kim S, Sanford DE, Linehan DC, Hikida M, Kumosaki T, Novack DV, Faccio R (2013) Down-regulation of PLC $\gamma 2-\beta$-catenin pathway promotes activation and expansion of myeloid-derived suppressor cells in cancer. J Exp Med 210: 2257-2271.

Castro Alves C, Rosivatz E, Schott C, Hollweck R, Becker I, Sarbia M, Carneiro F, Becker KF (2007) Slug is overexpressed in gastric carcinomas and may act synergistically with SIP1 and Snail in the down-regulation of E-cadherin. J Pathol 211: 507-515.

Cervello M, Giannitrapani L, Labbozzetta M, Notarbartolo M, D'Alessandro N, Lampiasi N, Azzolina A, Montalto G (2004) Expression of WISPs and of their novel alternative variants in human hepatocellular carcinoma cells. Ann N Y Acad Sci 1028: 432-439.

Chen CC, Lau LF (2009) Functions and mechanisms of action of CCN matricellular proteins. Int J Biochem Cell Biol 41: 771-783.

Chen PP, Li WJ, Wang Y, Zhao S, Li DY, Feng LY, Shi XL, Koeffler HP, Tong XJ, Xie D (2007) Expression of Cyr61, CTGF, and WISP-1 correlates with clinical features of lung cancer. PLoS One 2: e534.

Coussens LM, Fingleton B, Matrisian LM (2002) Matrix metalloproteinase inhibitors and cancer: trials and tribulations. Science 295: 2387-2392.

Davies G, Martin TA, Ye L, Lewis-Russell JM, Mason MD, Jiang WG (2008) Phospholipase-C gamma-1 (PLCgamma-1) is critical in hepatocyte growth factor induced in vitro invasion and migration without affecting the growth of prostate cancer cells. Urol Oncol 26: 386-391.

Davies SR, Davies ML, Sanders A, Parr C, Torkington J, Jiang WG (2010) Differential expression of the CCN family member WISP-1, WISP-2 and WISP-3 in human colorectal cancer and the prognostic implications. Int $J$ Oncol 36: 1129-1136.

Davies SR, Watkins G, Mansel RE, Jiang WG (2007) Differential expression and prognostic implications of the CCN family members WISP-1, WISP2, and WISP-3 in human breast cancer. Ann Surg Oncol 14: 1909-1918.

Dhar G, Banerjee S, Dhar K, Tawfik O, Mayo MS, Vanveldhuizen PJ, Banerjee SK (2008) Gain of oncogenic function of p53 mutants induces invasive phenotypes in human breast cancer cells by silencing CCN5/WISP-2. Cancer Res 68: 4580-4587.
Dhar G, Mehta S, Banerjee S, Gardner A, McCarty BM, Mathur SC, Campbell DR, Kambhampati S, Banerjee SK (2007) Loss of WISP-2/CCN5 signaling in human pancreatic cancer: a potential mechanism for epithelial-mesenchymaltransition. Cancer Lett 254: 63-70.

Enderling H, Hlatky L, Hahnfeldt P (2009) Migration rules: tumours are conglomerates of self-metastases. Br J Cancer 100: 1917-1925.

Feng L, Reynisdottir I, Reunisson J (2012) The effect of PLC- $\gamma 2$ inhibitors on the growth of human tumour cells. Eu J Med Chem 54: 463-469.

Fritah A, Saucier C, De Wever O, Bracke M, Bieche I, Lidereau R, Gespach C, Drouot S, Redeuilh G, Sabbah M (2008) Role of WISP-2/CCN5 in the maintenance of a differentiated and noninvasive phenotype in human breast cancer cells. Mol Cell Biol 28: 1114-1123.

Jiang WG, Davies G, Martin TA, Parr C, Watkins G, Mason MD, Mokbel K, Mansel RE (2005) Targeting matrilysin and its impact on tumor growth in vivo: the potential implications in breast cancer therapy. Clin Cancer Res 11: 6012-6019.

Jiang WG, Hiscox S, Hallett MB, Horrobin DF, Mansel RE, Puntis MCA (1995) Regulation of the expression of E-cadherin on human cancer cells by gamma-linolenic acid (GLA). Cancer Res 55: 5043-5048.

Jiang WG, Hiscox SE, Parr C, Martin TA, Matsumoto K, Nakamura T, Mansel RE (1999) Antagonistic effect of NK4, a novel hepatocyte growth factor variant, on in vitro angiogenesis of human vascular endothelial cells. Clin Cancer Res 5: 3695-3703.

Jiang WG, Watkins G, Lane J, Cunnick GH, Douglas-Jones A, Mokbel K, Mansel RE (2003) Prognostic value of rho GTPases and rho guanine nucleotide dissociation inhibitors in human breast cancers. Clin Cancer Res 9: 6432-6440.

Jones NP, Peak J, Brader S, Eccles SA, Katan M (2005) PLCgammal is essential for early events in integrin signalling required for cell motility. J Cell Sci 118: 2695-2706.

Keese CR, Wegener J, Walker SR, Giaever I (2004) Electrical wound-healing assay for cells in vitro. Proc Natl Acad Sci USA 101: 1554-1559.

Lattanzio R, Piantelli M, Falasca M (2013) Role of phospholipase C in cell invasion and metastasis. Adv Biol Regul 53: 309-318.

Leber MF, Efferth T (2009) Molecular principles of cancer invasion and metastasis (review). Int J Oncol 34: 881-895.

Leung E, Hung JM, Barkerb D, Reynisson JO (2014) The effect of a thieno[2,3b]pyridine PLC-g inhibitor on the proliferation, morphology, migration and cell cycle of breast cancer cells. Med Chem Commun 5: 990106.

Li SP, Junttila MR, Han J, Kahari VM, Westermarck J (2003) p38 Mitogenactivated protein kinase pathway suppresses cell survival by inducing dephosphorylation of mitogen-activated protein/extracellular signalregulated kinase kinase1,2. Cancer Res 63: 3473-3477.

Lombaerts M, van Wezel T, Philippo K, Dierssen JW, Zimmerman RM, Oosting J, van Eijk R, Eilers PH, van de Water B, Cornelisse CJ, CletonJansen AM (2006) E-cadherin transcriptional downregulation by promoter methylation but not mutation is related to epithelial-tomesenchymal transition in breast cancer cell lines. Br J Cancer 94: 661-671.

Lorenzatti G, Huang W, Pal A, Cabanillas AM, Kleer CG (2011) CCN6 (WISP3) decreases ZEB1-mediated EMT and invasion by attenuation of IGF-1 receptor signaling in breast cancer. J Cell Sci 124: 1752-1758.

Martin TA, Goyal A, Watkins G, Jiang WG (2005) Expression of the transcription factors snail, slug, and twist and their clinical significance in human breast cancer. Ann Surg Oncol 12: 488-496.

Nazarenko IA, Bhatnagar SK, Hohman RJ (1997) A closed tube format for amplification and detection of DNA based on energy transfer. Nucleic Acid Res 25: 2516-2521.

Nozawa H, Howell G, Suzuki S, Zhang Q, Qi Y, Klein-Seetharaman J, Wells A, Grandis JR, Thomas SM (2008) Combined inhibition of PLC\{gamma\}-1 and c-Src abrogates epidermal growth factor receptor-mediated head and neck squamous cell carcinoma invasion. Clin Cancer Res 14: 4336-4344.

Pennica D, Swanson TA, Welsh JW, Roy MA, Lawrence DA, Lee J, Brush J, Taneyhill LA, Deuel B, Lew M, Watanabe C, Cohen RL, Melhem MF, Finley GG, Quirke P, Goddard AD, Hillan KJ, Gurney AL, Botstein D, Levine AJ (1998) WISP genes are members of the connective tissue growth factor family that are up-regulated in wnt-1-transformed cells and aberrantly expressed in human colon tumors. Proc Natl Acad Sci USA 95: $14717-14722$

Rosivatz E, Becker I, Specht K, Fricke E, Luber B, Busch R, Höfler H, Becker KF (2002) Differential expression of the epithelial-mesenchymal transition regulators snail, SIP1, andtwist in gastric cancer. Am J Pathol 161: 1881-1891. 
Russo JW, Castellot JJ (2010) CCN5: biology and pathophysiology. J Cell Commun Signal 4: 119-130.

Sengupta K, Banerjee S, Dhar K, Saxena NK, Mehta S, Campbell DR, Banerjee SK (2006) WISP-2/CCN5 is involved as a novel signaling intermediate in phorbol ester-protein kinase Calpha-mediated breast tumor cell proliferation. Biochemistry 45: 10698-10709.

Soon LL, Yie TA, Shvarts A, Levine AJ, Su F, Tchou-Wong KM (2003) Overexpression of WISP-1 down-regulated motility and invasion of lung cancer cells through inhibition of Rac activation.J Biol Chem 278: $11465-11470$

Tian C, Zhou ZG, Meng WJ, Sun XF, Yu YY, Li L, Luo HZ, Yang L, Zhou B, $\mathrm{Gu} J$ (2007) Overexpression of connective tissue growth factor WISP-1 in Chinese primary rectal cancer patients. World J Gastroenterol 13: 3878-3882.

Vandooren J, Geurts N, Martens E, Van den Steen PE, Opdenakker G (2013) Zymography methods for visualizing hydrolytic enzymes. Nat Methods 10: 211-220.

Vesuna F, van Diest P, Chen JH, Raman V (2008) Twist is a transcriptional repressor of E-cadherin gene expression in breast cancer. Biochem Biophys Res Commun 367: 235-241.

Weiss MB, Abel EV, Mayberry MM, Basile K, Berger AC, Aplin AE (2012) TWIST1 is an ERK1/2 effector that promotes invasion and regulates MMP-1 expression in human melanoma cells. Cancer Res 72: 6382-6392.
Xie D, Nakachi K, Wang H, Elashoff R, Koeffler HP (2001) Elevated levels of connective tissue growth factor, WISP-1, and CYR61 in primary breast cancers associated with more advanced features. Cancer Res 61: 8917-8923.

Yang J, Mani SA, Donaher JL, Ramaswamy S, Itzykson RA, Come C, Savagner P, Gitelman I, Richardson A, Weinberg RA (2004) Twist, a master regulator of morphogenesis, plays an essential role in tumor metastasis. Cell 117: 927-939.

Zeisberg M, Neilson EG (2009) Biomarkers for epithelial-mesenchymal transitions. J Clin Invest 119: c1429-c1437.

Zhang P, Zhao Y, Zhu X, Sedwick D, Zhang X, Wang Z (2011) Cross-talk between phospho-STAT3 and PLCgammal plays a critical role in colorectal tumorigenesis. Mol Cancer Res 9: 1418-1428.

Zoubine MN, Banerjee S, Saxena NK, Campbell DR, Banerjee SK (2001) WISP-2: a serum-inducible gene differentially expressed in human normal breast epithelial cells and in MCF-7 breast tumor cells. Biochem Biophys Res Commun 282: 421-425.

Zuker M (2003) Mfold web server for nucleic acid folding and hybridization prediction. Nucleic Acids Res 31: 3406-3415.

This work is published under the standard license to publish agreement. After 12 months the work will become freely available and the license terms will switch to a Creative Commons AttributionNonCommercial-Share Alike 4.0 Unported License.

Supplementary Information accompanies this paper on British Journal of Cancer website (http://www.nature.com/bjc) 